\title{
HUBUNGAN PERILAKU DENGAN INFEKSI SOIL TRANSMITTED HELMINTHS PADA ANAK SEKOLAH DASAR MI ASAS ISLAM KALIBENING, SALATIGA
}

\author{
Liena Sofiana \\ Fakultas Kesehatan Masyarakat, Universitas Ahmad Dahlan, Yogyakarta
}

\begin{abstract}
Background : Occurence of Soil Transmitted Helminths infection in Indonesia still very high. That wormy number at elementary school student are $60-80 \%$. Soil Transmitted Helminths infection is a health problem in tropical and subtropical regions. The number of patients infected with more than one species of intestinal worms such as Ascaris, Trichuris and hookworm. In the tropics, the soil moist and protected from sunlight is a good condition to continue the transmission of Ascaris continuously. Clay is a good place for development and remain infective Ascaris eggs around the puddle of water because of drought escape. When exposed to rain, water mixed with soil to spread to vegetables or fruits are eaten or later come flying through the air and will contaminate the environment. In areas with poor sanitation conditions and dense population prevalence will increase. Her case is more frequent in children mainly aged 5-9 years compared with adults. Another contributing factor is the knowledge, attitudes, and behavior of healthy people against infections Soil Transmitted Helminths. This study to investigate the correltion between the behavior with the Soil Transmitted Helminths infection in children of primary school.

Method : It is an analytic and observational study with cross sectional design. The data is collected using faecal survey is using Kato Katz method and interview is using questionnaire the 33 respondents.

Result : The result of the study showed that there is not any significant correlation between behavior and the Soil Transmitted Helminths infection $(p=0,616)$ of the elemntary school children in MI Asas Islam Kalibening, Tingkir Of Salatiga District.

Conclusion : There is statistically not any significant correlation between behavior and the soil transmitted Helminths infection.
\end{abstract}

Keywords : Soil Transmitted Helminths, behavior.

\section{PENDAHULUAN}

Angka kejadian infeksi Soil Transmitted Helminths di Indonesia masih cukup tinggi. Angka tersebut pada siswa sekolah dasar mencapai 60-80\%. Infeksi Soil Transmitted Helminths merupakan masalah kesehatan di daerah tropis dan subtropis. Banyaknya penderita yang terinfeksi lebih dari satu spesies cacing usus seperti Ascaris, Trichuris dan cacing tambang. Ascariasis dapat mengakibatkan protein energy malnutrition. Pada anak-anak yang diinfeksi 13-14 cacing dewasa dapat kehilangan 4 gram protein dari diet yang mengandung 35-50 gram protein/hari. Sedangkan infeksi Trichuris trichiura dapat menyebabkan anemia, malnutrisi dan diare pada anak-anak dengan infeksi berat.

Di daerah tropis, tanah lembab dan terlindung dari sinar matahari merupakan kondisi yang baik untuk tetap berlangsungnya transmisi Ascaris secara terus menerus. Tanah liat merupakan tempat yang baik untuk perkembangan telur Ascaris dan tetap infektif di sekitar genangan air karena terhindar dari kekeringan. Bila terkena hujan, air bercampur tanah menyebar ke tanaman sayuran atau buah-buahan yang selanjutnya 
ikut termakan atau beterbangan di udara dan akan mencemari lingkungan. Di daerah dengan kondisi sanitasi yang jelek dan penduduk padat prevalensinya akan meningkat. Kasusnya lebih sering pada anak-anak terutama umur 5-9 tahun dibandingkan dengan orang dewasa. Faktor lain yang berperan adalah pengetahuan, sikap, dan perilaku sehat masyarakat terhadap infeksi Soil Transmitted Helminths.

Trichuris trichiura atau cacing cambuk merupakan cacing yang bersifat kosmopolit, terutama ditemukan pada daerah panas dan lembab, seperti di Indonesia. Daerah penyebarannya sama dengan ascariasis, prevalensinya tinggi pada keadaan sosial ekonomi yang rendah. Cacing ini menginfeksi segala umur dan semua jenis kelamin. Sama dengan cacing Ascaris, cacing ini pun cara penularannya melalui makanan/minuman yang tercemar telur infektif, dengan faktor resiko yang sama pula.

Daerah Salatiga sebagai daerah survei yang beriklim tropis merupakan daerah berbukit yang sangat ideal bagi perkembangbiakan cacing Soil Transmitted Helminths. Aneka permainan pada anak usia sekolah pada umumnya hampir selalu dilakukan di luar rumah/tanah, yang merupakan media bagi perkembangbiakan Soil Transmitted Helminths, seperti A.lumbricoides, Hookworm, dan T.Trichiura. Kebiasaan buruk anakanak seperti tidak mencuci tangan setelah bermain di tanah, apalagi ketika akan makan/minum hanya akan mempermudah masuknya telur cacing ke dalam usus mereka.

Berdasarkan data bahwa banyak anak usia sekolah di Wilayah Kerja Puskesmas Sidorejo Kidul yang memiliki berat badan rendah, sehingga memunculkan dugaan bahwa hal tersebut kemungkinan disebabkan oleh adanya infeksi Soil Transmitted Helminths pada anak usia sekolah, sehingga perlu dilakukan penelitian lebih lanjut mengenai hubungan perilaku dengan infeksi Soil Transmitted Helminths.

\section{METODE PENELITIAN}

Jenis penelitian ini adalah penelitian observasional dengan menggunakan rancangan cross secsional. Analisis data meliputi analisis univariat (deskriptif) dan analisis bivariat menggunakan uji chi square. Penelitian ini dilakukan di Madrasah Ibtidaiyah Asas Islam Kalibening Kecamatan Tingkir Kota Salatiga. Pengambilan sampel pada penelitian ini dengan menggunakan totality sampling. Pemeriksaan tinja dilakukan pada siswa kelas V dan VI sebanyak 33 anak.

\section{HASIL PENELITIAN DAN PEMBAHASAN}

Pemeriksaan tinja dengan metode Kato Katz terhadap 33 anak sekolah dasar di Madrasah Ibtidaiyah Asas Islam Kalibening Kecamatan Tingkir Kota Salatiga, didapatkan 3 anak yang positif terinfeksi Soil Transmitted Helminths. Hasil pemeriksaan tinja tersebut dapat dilihat pada tabel 1. 
Tabel 1. Hasil pemeriksaan tinja di MI Asas Islam Kalibening Kecamatan Tingkir Kabupaten Salatiga

\begin{tabular}{lcc}
\hline \multicolumn{1}{c}{ Responden } & Frekuensi & Persentase(\%) \\
\hline Positif & 3 & 9,1 \\
Negatif & 30 & 90,9 \\
\hline \multicolumn{1}{c}{ Total } & 33 & 100,0 \\
\hline
\end{tabular}

Pada tabel 1. terlihat bahwa anak yang terinfeksi Soil Transmitted Helminths sebanyak 3 anak $(9,1 \%)$, sedangkan anak yang tidak terinfeksi Soil Transmitted Helminths sebanyak 30 anak $(90,9 \%)$.

Tabel 2. Aspek Perilaku dengan Kejadian Infeksi Kecacingan di MI Asas Islam Kalibening Kecamatan Tingkir Kabupaten Salatiga

\begin{tabular}{|c|c|c|c|c|c|c|}
\hline \multirow[b]{2}{*}{ Aspek perilaku } & & \multicolumn{2}{|c|}{ Positif } & \multicolumn{2}{|c|}{ Negatif } & \multirow[t]{2}{*}{$\mathrm{p}$} \\
\hline & & $\mathrm{n}$ & $\%$ & $\mathrm{n}$ & $\%$ & \\
\hline \multirow[t]{2}{*}{ Mencuci tangan sebelum makan } & Ya & 3 & 9,1 & 29 & 87,87 & 0,909 \\
\hline & Tidak & 0 & 0 & 1 & 3,03 & \\
\hline \multirow[t]{2}{*}{ Mencuci tangan dengan sabun setelah berak } & Ya & 3 & 9,1 & 27 & 81,80 & 0,744 \\
\hline & Tidak & 0 & 0 & 3 & 9,1 & \\
\hline \multirow[t]{2}{*}{ Berak di jamban } & Ya & 3 & 9,1 & 27 & 81,80 & 0,744 \\
\hline & Tidak & 0 & 0 & 3 & 9,1 & \\
\hline \multirow[t]{2}{*}{ Mandi dan membersihkan badan 2 kali sehari } & Ya & 3 & 9,1 & 29 & 87,87 & 0,909 \\
\hline & Tidak & 0 & 0 & 1 & 3,03 & \\
\hline \multirow[t]{2}{*}{ Memotong kuku 1 minggu sekali } & Ya & 3 & 9,1 & 26 & 78,78 & 0,670 \\
\hline & Tidak & 0 & 0 & 4 & 12,12 & \\
\hline \multirow[t]{2}{*}{ Masih menggigit kuku jari tangan } & Ya & 2 & 6,06 & 0 & 0 & 0,176 \\
\hline & Tidak & 1 & 3,03 & 30 & 90,91 & \\
\hline \multirow[t]{2}{*}{ Memakai alas kaki apabila bermain dan keluar rumah } & Ya & 3 & 9,1 & 29 & 87,87 & 0,909 \\
\hline & Tidak & 0 & 0 & 1 & 3,03 & \\
\hline \multirow[t]{2}{*}{ Menggunakan air bersih untuk mandi, masak dan minum } & Ya & 3 & 9,1 & 30 & 90,91 & \\
\hline & Tidak & 0 & 0 & 0 & 0 & \\
\hline
\end{tabular}

Tabel diatas menunjukkan bahwa perilaku anak sekolah dasar tidak ada hubungan bermakna dengan kejadian infeksi Soil Transmitted Helminths, karena hasil uji chi square menunjukkan nilai $p>0,05$. Aspek perilaku diatas dilakukan pengkategorian sehingga akan didapatkan perilaku anak baik dan perilaku tidak baik. 
Tabel 3. Karakteristik subyek penelitian berdasarkan perilaku dengan infeksi Soil Transmitted Helminths di Madrasah Ibtidaiyah Asas Islam Kalibening Kecamatan Tingkir Kabupaten Salatiga

\begin{tabular}{lccccccc}
\hline \multirow{2}{*}{ Sikap } & \multicolumn{6}{c}{ Infeksi Soil Transmitted Helminths } & \multirow{2}{*}{$p$} \\
\cline { 2 - 6 } & \multicolumn{2}{c}{ Positif } & \multicolumn{2}{c}{ Negatif } & \multicolumn{2}{c}{ Total } & \\
\cline { 2 - 6 } & $\mathrm{n}$ & $\%$ & $\mathrm{n}$ & $\%$ & $\mathrm{n}$ & $\%$ & \\
\hline Tidak baik & 1 & 3 & 13 & 39,4 & 14 & 42,4 & \multirow{2}{*}{0,616} \\
Baik & 2 & 6,1 & 17 & 51,5 & 19 & 57,6 & \\
\hline Total & 3 & 9,1 & 30 & 90,9 & 33 & 100,0 & \\
\hline
\end{tabular}

Tabel diatas menunjukkan bahwa 6,1\% responden yang terinfeksi penyakit Soil Transmitted Helminths memiliki perilaku yang baik, sedangkan responden yang memiliki perilaku tidak baik yang terkena kecacingan hanya 3\%. Melihat kecenderungan proporsi tersebut menunjukkan arah hubungan yang negatif. Hasil analisis statistik diperoleh nilai $p=0,616(p>0,05)$ sangat tidak signifikan berarti tidak ada hubungan antara perilaku responden dengan kejadian infeksi Soil Transmitted Helminths.

Hasil analis bivariat menunjukkan tidak ada hubungan yang signifikan antara perilaku dengan infeksi Soil Transmitted Helminths pada anak sekolah di Madrasah Ibtidaiyah Asas Islam Kalibening Kecamatan Tingkir Kabupaten Salatiga. Hasil penelitian yang tidak sama, menunjukkan bahwa ada hubungan antara perilaku anak dengan infeksi kecacingan pada anak sekolah dasar di Kelurahan Pannampu Kecamatan Tallo Kotamadya Makassar ${ }^{1}$. Perilaku bukan merupakan faktor risiko yang berhubungan langsung dengan infeksi Soil Transmitted Helminths, hal tersebut dikarenakan anak-anak telah melakukan perilaku sehat dalam kehidupan sehari-hari.

Beberapa aspek dalam penelitian ini ada 8 perilaku, dan tidak menunjukkan hubungan yang bermakna dengan infeksi Soil Transmitted Helminths yaitu mencuci tangan sebelum makan $(p=0,909)$, memotong kuku 1 minggu sekali $(p=0,909)$ dan masih menggigit kuku jari tangan $(p=0,670)$. Berbeda dengan penelitian lain bahwa ada hubungan yang signifikan antara kebiasan mencuci tangan dengan sabun dengan prevalensi kecacingan ${ }^{2}$. Infeksi Soil Transmitted Helminths pada responden yang mempunyai kebiasaan mencuci tangan setelah berak $(p=0,744)$ dapat dikatakan bahwa tidak ada hubungan dengan infeksi Soil Transmitted Helminths. Tidak adanya hubungan ini dikarenakan anak-anak sudah membiasakan mencuci tangan dengan sabun. Kebiasaan mencuci tangan memakai sabun dan air mempunyai peranan penting dengan pencegahan infeksi kecacingan, karena dengan mencuci tangan dengan air dan sabun dapat lebih efektif menghilangkan kotoran yang ada di permukaan kulit. Pemelitian lain menunjukkan ada hubungan antara kebiasaan tidak mencuci tangan setelah $B A B$ dengan infeksi kecacingan, ada hubungan disini dikarenakan tidak tersedianya sabun di jamban ${ }^{3}$. Anak-anak sering tidak mencuci tangan setelah BAB, padahal penularan infeksi ini secara langsung melalui tangan yang telah terkontaminasi dengan telur cacing yang infektif.

Hasil penelitian lain menunjukkan bahwa pada kuku jari tangan anak sekolah dasar di Jakarta ditemukan telur cacing Ascaris lumbricoides dan Trichuris trichiura. Kuku jari tangan yang kotor dan terkontaminasi tanah yang mengandung telur infektif merupakan media dalam penularan penyakit kecacingan ${ }^{4}$. Manusia terinfeksi Ascaris lumbricoides dan Trichuris trichiura karena menelan telur infektif yang mengkontaminasi makanan, minuman dan alat makan ${ }^{5}$.

Aspek yang lain yaitu berak (BAB) di jamban, menunjukkan bahwa tidak ada hubungan dengan infeksi Soil Transmitted Helminths $(p=0,744)$, hal ini dikarenakan 
semua anak sudah tidak berak di sembarang tempat. Berbeda dengan penelitian lain perilaku tidak pernah berak di sembarang tempat menunjukkan ada hubungan yang bermakna, hal ini disebabkan karena kurangnya kesadaran masyarakat dalam menyediakan jamban dan berak masih di sembarang tempat ${ }^{3}$. Banyak ditemukan telur ascaris $(28,3 \%)$ di dekat jamban dan di tempat buang air besar lainnya $(71,4 \%)$ dan didekat sumur atau tempat untuk mencuci $(43,3 \%)^{6}$.

Beberapa aspek lain yang tidak berhubungan adalah memakai alas kaki apabila bermain dan keluar rumah $(p=909)$. Perilaku masyarakat membuang air besar di sembarang tempat dan kebiasaan memakai alas kaki mempunyai intensitas infeksi cacing tambang dengan pola transmisi umumnya terjadi di dekat rumah ${ }^{7}$. Infeksi cacing tambang pada manusia melalui penetrasi larva filariform yang terdapat di tanah, masuk melalui kulit, dan biasanya terjadi ketika berjalan tanpa memakai alas kaki di atas tanah yang terkontaminasi oleh larva cacing tambang ${ }^{5}$.

\section{SIMPULAN DAN SARAN}

Berdasarkan uraian diatas maka dapat ditarik kesimpulan bahwa tidak ada hubungan antara pengetahuan, sikap, perilaku dengan infeksi Soil Transmitted Helminths pada anak sekolah dasar di Madrasah Ibtidaiyah Kalibening Kecamatan Tingkir Kabupaten Salatiga. Perlu dilakukan pemantauan secara terus menerus terutama bagi anak sekolah dasar yang berisiko tinggi. Hasil penelitian yang sama dengan

\section{DAFTAR PUSTAKA}

1. Arif, Muh. Iqbal. Faktor Risiko Terjadinya infeksi kecacingan (ascaris lumbricoides dan trichuris trichiura) pada anak sekolah dasar di kelurahan pannapu kec. Tallo kotamadya makassar. Tesis, IKM UNAIR. 2004

2. Hidayat, Taufik. Kesehatan Lingkungan, Higiene Perseorangan dan Intensitas Penyakit Kecacingan dengan Status Gizi pada Anak Sekolah Dasar di Kota Mataram. Tesis, Program Pascasarjana Universitas Gadjah Mada, Yogyakarta. 2002

3. Wachidanijah, Sutomo, A.H, Padmawati, R.S. Pengetahuan, Sikap dan Perilaku Anak Serta Lingkungan Rumah dan Sekolah dengan Kejadian Infeksi Kecacingan Anak Sekolah Dasar (Studi di Kecamatan Prembun Kabupaten Kebumen). Berita Kedokteran Masyarakat, 18 (4) : 177-183. 2002

4. Tjitra,E. Penelitian Soil Transmitted Helminth di Indonesia. Cermin Dunia Kedokteran; 72: 5-11.1991

5. Gandahusada,S., IllahudeD.,H.,Pribadi,W. Helminthologi di dalam Parasitologi Kedokteran, hal 7-23. Balai Penerbit Fakultas Kedokteran Universitas Indonesia, Jakarta. 2006

6. Soeripto,N. ,Doeljachman,Sumarni,S. ,Sutarti ,Soil Transmitted Helminths in Yogyakarta, Buletin Penelitian Kesehatan, 1989;17;247-55.

7. Bakta, I.M. Aspek Epidemiologi Infeksi Cacing Tambang pada Penduduk Dewasa Desa Jagapati Bali. Medika; XXI (6). 1995 : 431-437. 